\title{
Mullerian adenosarcoma of the uterus associated with tamoxifen treatment for breast cancer
}

\section{Meme kanseri tanılı olguda tamoksifen tedavisi ile ilişili uterin Müllerian adenosarkom}

\author{
Yasin Ceylan'1, Emek Doğer¹, Ahmet Yiğit Çakıroğlu1, Çiğdem Vural2, İzzet Yücesoyl \\ ${ }_{1}^{1}$ Kocaeli University Faculty of Medicine, Department of Obstetrics and Gynecology Kocaeli, Turkey \\ ${ }^{2}$ Kocaeli University Faculty of Medicine, Department of Pathology, Kocaeli, Turkey
}

\begin{abstract}
Mullerian adenosarcoma following tamoxifen therapy is a rare condition. Our aim was to report the youngest patient in the literature with uterine mullerian adenosarcoma who was undergoing tamoxifen therapy for breast cancer. A premenopausal woman aged 38 years who was undergoing tamoxifen therapy for breast cancer, was admitted with symptoms of lower abdominal pain and irregular vaginal bleeding and malodorous vaginal discharge that had continued for at least 6 months. A pelvic examination revealed a large and malodorous polypoid mass protruding through the cervix and an enlarged uterus. A biopsy from the protruding polypoid mass was reported as a large area of necrosis with neoplastic mesenchymal cells. The patient underwent a total abdominal hysterectomy, bilateral salpingo-oopherectomy, pelvic-paraaortic lymph node dissection, and omentectomie. The histologic diagnosis was Mullerian adenosarcoma. As a result, she was discharged to the oncology department. The woman is alive and her chemoradiotherapy treatment is ongoing. The role of tamoxifen therapy in the development of endometrial neoplasms remains unclear, but all cases of endometrial thickening and vaginal bleeding must be investigated for Mullerian adenosarcoma in tamoxifen users.
\end{abstract}

Keywords: Breast cancer, tamoxifen, uterine Mullerian adenosarcoma

$\ddot{\mathbf{O} z}$

Meme kanseri tanılı olgularda tamoksifen tedavisine bağlı uterin Müllerian adenosarkom gelişimi nadir bir durumdur. Amacımız literatürde meme kanseri tanıll, tamoksifen tedavisine bağlı uterin müllerian adenosarkom gelişmiş en genç kadın hastayı rapor etmektir. Meme kanseri tedavisi için tamoksifen kullanan 38 yaşında premenapozal kadın hasta son 1-1,5 yıldır devam eden alt batın ağrısı, anormal vajinal kanama ve kötü kokulu vajinal akıntı tariflemektedir. Pelvik muayenede serviksten dışarı doğru uzanan ve uterusu büyüten büyük, kötü kokulu polipoid yapı izlendi. Polipoid yapıdan alınan biyopsi örneklerinde geniş nekroz alanları ve neoplastik mezenşimal hücreler tespit edildi. Hastaya total abdominal histerektomi, bilateral salpingoooferektomi, pelvik ve paraaortik lenf nodu disseksiyonu ve omentektomi yapıldı. Histolojik olarak Müllerian adenosarkom tanısı kondu ve hasta onkoloji bölümüne yönlendirildi. Hasta hala yaşıyor olup kemoterapi almaktadır. Endometrial tümörlerinin gelişiminde tamoksifen tedavisinin rolü belirsizdir, ama endometriyal kalınlaşma ve vajinal kanaması olan tamoksifen kullanan hastaların Müllerian adenosarkom açısından araştırılması gerekir.

Anahtar Kelimeler: Meme kanseri, tamoksifen, uterim Müllerian adenosarkom

\section{Introduction}

Mullerian adenosarcoma is an uncommon variant of mullerian mixed tumor of the uterus. Mullerian adenosarcoma accounts for only about $5-8 \%$ of all uterine sarcomas and more seldom on extrauterine sites including the cervix, ovary, vagina, fallopian tubes, and intestinal serosa. There have been a number of case reports of mullerian adenosarcoma arising in women undergoing tamoxifen or toremifene treatment or with endogenous hyperestrogenism(1).

Tamoxifen has been shown to increase survival for women with breast cancer and decrease the risk of estrogen receptor-positive breast cancer in high-risk female populations(2). Despite its benefits, tamoxifen has weakly estrogenic effects that can produce endometrial cell proliferation and increases the risk of endometrial cancer. However, the magnitude of increased risk remains unclear, recent studies indicate that the risk associated with tamoxifen may be substantially higher for rare, aggressive forms of uterine tumors, notably uterine sarcomas(2-8). To date, 16 cases of mullerian adenosarcoma of the uterus associated with tamoxifen therapy have been reported in the English literature(2-11).

Although most patients were diagnosed between the age of $40-65$ years, $10 \%$ were aged less than 40 years(1). In the

Address for Correspondence/Yazışma Adresi: Yasin Ceylan, MD,

Kocaeli University Faculty of Medicine, Department of Obstetrics and Gynecology Kocaeli, Turkey

Phone: +90 5357489729 E-mail: md.yasinceylan@yahoo.com

Received/Geliş Tarihi : 01.08.2015

Accepted/Kabul Tarihi : 26.11.2015 
present study, we report the youngest woman in the literature with uterine mullerian adenosarcoma who was undergoing tamoxifen therapy for breast cancer.

\section{Case Report}

A multiparous woman aged 38 years was admitted to our hospital with symptoms of lower abdominal pain and irregular vaginal bleeding and malodorous vaginal discharge that had continued for at least 6 months. She had a history of breast cancer. She had undergone a modified radical left mastectomy including left axillary dissection four years ago. A pathologic examination had revealed a grade 3 , progesterone receptorpositive and c-erb-B2 score 3, but estrogen receptor-negative invasive ductal carcinoma. Post-operative treatment consisted of four chemotherapy courses using the CAF regimen (cyclophoshamide $600 \mathrm{mg} / \mathrm{m}^{2}$, adriamycin $60 \mathrm{mg} / \mathrm{m}^{2}$, 5-FU $600 \mathrm{mg} / \mathrm{m}^{2}$ ) and nine weeks of herceptin $6 \mathrm{mg} / \mathrm{kg}$ and docetaxel $75 \mathrm{mg} / \mathrm{m}^{2}$. After chemotherapy courses, she had been treated with 20 mg/day tamoxifen (Nolvadex, AztraZeneca Inc, UK) for 30 months.

On admission, a pelvic examination revealed a large and malodorous polypoid mass protruding through the cervix and an enlarged uterus. Magnetic resonance images showed that a 192x100 mm uterus and a 75x65 mm solid heterogeneous mass filled the endometrial cavity without signs of invasion to surrounding tissues (Figure la). A biopsy from the protruding polypoid mass was reported as a large area of necrosis with neoplastic mesenchymal cells. Fresh frozen sections taken during the operation revealed an endometrial stromal sarcoma so a total abdominal hysterectomy, and bilateral salpingooopherectomy were performed. Pelvic-paraaortic lymph node dissection and omentectomy were added because there were palpable lymph nodes. Macroscopically, the tumor appeared as a polipoid lesion that extended into the endometrial cavity (Figure 1b). The cut surface of tumor showed cystic spaces filled with watery or mucoid fluid, surrounded by tan to gray tissue. More than half of the tumor was myometrial invasion. Histopathologically, the tumor was a biphasic lesion with benign epithelial elements and a sarcomatous stroma. Tubular glands, cysts, and cleft-like spaces were distributed throughout the tumor. These glands were lined by a benign proliferative endometrioid type epithelia. The mesenchymal component consisted of low-grade sarcoma, which was typically more cellular around the glands resulting in periglandular cuffs (Figure 2a). In these cellular areas, there was a maximum of 9 mitotic figures/10 HPF; the sarcomatous cells appeared to contain focal atypia and pleomorphic endometrial stromal cells or fibroblasts (Figure 2b). Immunohistochemically, the benign-appearing epithelial cells and sarcomatous tumor cells showed nuclear reaction with progesterone receptor and estrogen receptor (Figure 2c), and stromal cells showed cytoplasmic reaction with CD10 (Figure 2d). The final histologic diagnosis was mullerian adenosarcoma; the cervix, bilateral adnexa, pelvic-paraaortic lymph nodes, and
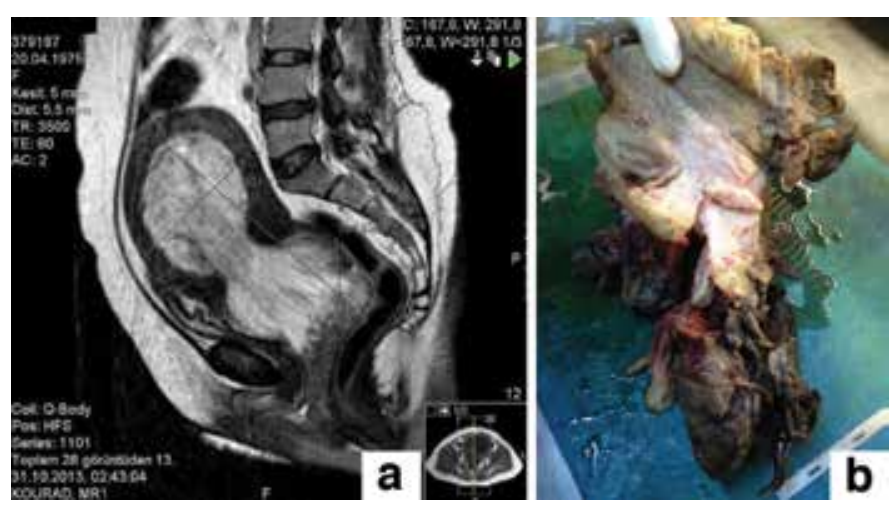

Figure 1. a: Magnetic resonance images showed a bilobular solid heterogeneous mass that filled the endometrial cavity. b: Macroscopically, the tumor was polipoid lesion extending into the endometrial cavity
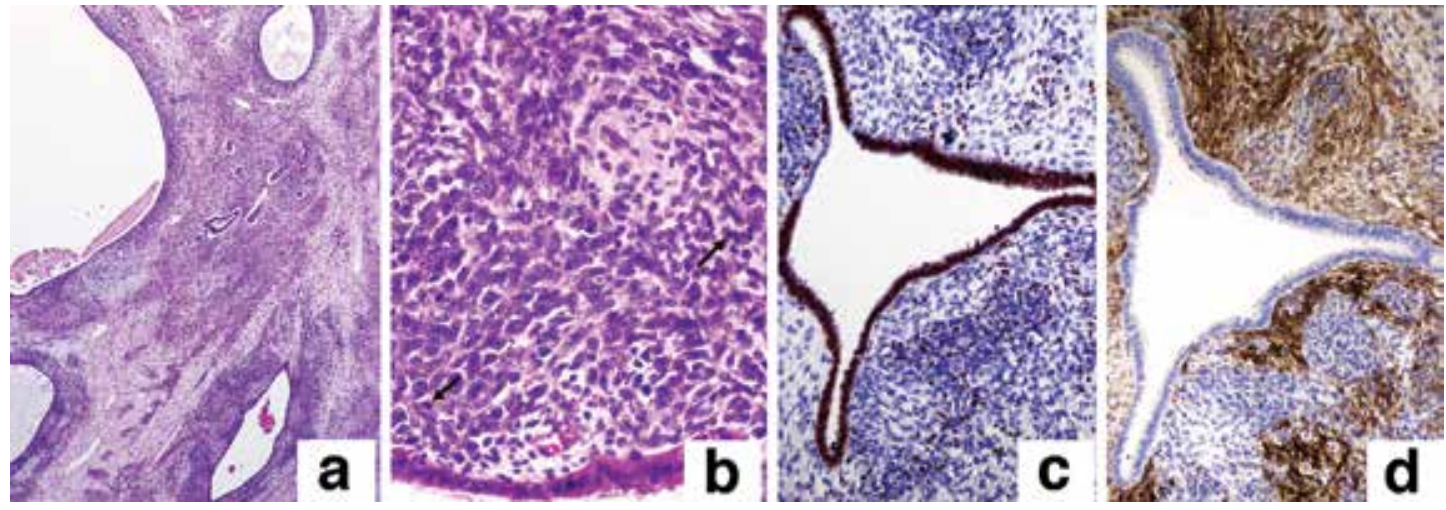

Figure 2. a: The tubular glands were lined by a benign proliferative endometrioid-type epithelia and the mesenchymal component consisted of low-grade sarcoma, which was typically more cellular around the glands resulting in periglandular cuffs. b: The sarcomatous cells appeared to contain focal atypia and pleomorphic endometrial stromal cells or fibroblasts. c: Immunohistochemically, the benign-appearing epithelial cells and sarcomatous tumor cells showed nuclear reaction with progesterone receptor and estrogen receptor d: Immunohistochemically, stromal cells showed cytoplasmic reaction with CD10 
omentum appeared unremarkable. The woman had stage IC disease according to the 2009 International Federation of Gynecology and Obstetrics Staging System for Uterine Adenosarcoma.

As a result, the patient was treated with adjuvant chemotherapy courses using doxorubicin, mesna, and ifosfamide (Day 1: Doxorubicin $50 \mathrm{mg} / \mathrm{m}^{2}$ over 15 minutes, followed by ifosfamide $5 \mathrm{~g} / \mathrm{m}^{2}$ via 24 -hour continuous IV admixed with mesna $6 \mathrm{~g} / \mathrm{m}^{2}$ for 36-hour through continuous IV. The cycle is being repeated every 3 weeks). After four chemotherapy courses, she is still alive although with vertebral bone metastasis.

\section{Discussion}

Tamoxifen has been used for the management of breast cancer for more than 40 years(7). Despite its therapeutic effect on breast carcinoma, its estrogenic effect on the endometrium may also be complicated by a number of endometrial lesions such as hyperplasia, polyps, endometriosis, carcinoma, and less frequently mesenchymal and mixed epithelial-mesenchymal uterine tumors such as adenomyoma, leiomyoma, and adenosarcoma(3). Endometrial adenocarcinoma is the most common malignancy associated with tamoxifen therapy. Both dosage and duration of treatment may be related to the development of uterine malignancies; tamoxifen dosage as low as $20 \mathrm{mg}$ /day has been shown to increase cancer risk in patients. Moreover, tamoxifen treatment for longer than 2 years is accepted as the highest risk factor, although the majority of patients develop endometrial carcinoma within 2 years(2). Tamoxifen-associated Mullerian adenosarcoma of the uterus has rarely been described. Thus, the estrogenic effect of tamoxifen on the endometrium may occasionaly also be complicated by mixed epithelial-mesenchymal or mesenchymal tumors. Endometrial stromal cells also contain estrogen receptors and Mullerian adenosarcomas are occasionally associated with longterm tamoxifen therapy(2-11).

Mullerian adenosarcoma is differentiated from the more common uterine carcinosarcomas by the presence of a benign or atypical neoplastic glandular component with a well-differentiated epithelial lining and low-grade malignant sarcomatous stromal structure, and biologic behaviors that show low malignant potential(1). The majority of patients who are diagnosed as having Mullerian adenosarcoma are postmenopausal and they present with abnormal vaginal bleeding or abdomino-pelvic pain. These tumors are usually single solitary polypoid masses that arise from the uterine fundus and project to the endometrial cavity, which appear to contain necrotic soft areas $(4,10)$. Treatment of primary disease is surgical with total abdominal hysterectomy but the role of staging with lymphadenectomy and/or oophorectomy is a subject of debate. A separate analysis of the Surveillance, Epidemiology, and End Results (SEER) database reported nodal metastases in $3.1 \%$ of 262 women who underwent lymphadenectomy for adenosarcoma. The reported experiences to date indicate that lymphadenectomy may not be necessary for staging all patients with uterine adenosarcoma. There is no consensus regarding complementary treatments. The benefit of such therapy in an adjuvant setting has not been demonstrated. Patients with sarcomatous overgrowth, deep myometrial invasion, lymphovasculer space invasion, and higher stage disease, which would indicate a worse prognosis, are more likely to have nodal metastases. Therefore, physicians consider adjuvant therapy regardless of nodal status. Most patients are diagnosed at an early stage and have a good prognosis with surgery alone but they have a higher risk of recurrence and death because of sarcomatous overgrowth and advanced stage disease(12).

To our knowledge, only 16 cases of Mullerian adenosarcoma following tamoxifen therapy have been reported in the literature(2-11). There are also three cases of uterine adenosarcoma in patients who had used hormonal agents for a previous diagnosis of breast cancer, reported by Carroll et al.(12). In these 16 cases, the women had received tamoxifen for periods of 5 months or up to 4 years, but only 2 patients, who were reported by Jagavkar et al.(5) and Arici et al.(6) had received tamoxifen for more than 5 years. The patients' age range in the literature is 42-76 years; the youngest patient was reported by Farhat and Fakhruddine, (11) a woman agaed 42 years.

Our aim was to report the youngest woman in the literature with Mullerian adenosarcoma who was undergoing tamoxifen therapy for breast cancer. As in the literature, endometrial sampling was not performed before tamoxifen therapy. Therefore, it is difficult to understand the relation between tamoxifen and pathologic diagnosis. The role of tamoxifen therapy in the development of Mullerian adenosarcoma remains unclear. Mullerian adenosarcoma screening with endometrial biopsy is not necessary before and during tamoxifen therapy, but all cases of endometrial thickening and vaginal bleeding must be investigated for Mullerian adenosarcoma in tamoxifen users.

\section{Authorship Contributions}

Ethics Committee Approval: The study were approved by the Kocaeli University of Local Ethics Committee, Informed Consent: Consent form was filled out by all participants, Concept: Yasin Ceylan, Emek Doğer, Design: Yasin Ceylan, Emek Doğer, Data Collection or Processing: Yasin Ceylan, Çiğdem Vural, Analysis or Interpretation: Yiğit Çakıroğlu, İzzet Yücesoy, Ahmet Yiğit Çakıroğlu, Literature Search: Yasin Ceylan, Writing: Yasin Ceylan, Emek Doğer, Peerreview: Internal peer-reviewed, Conflict of Interest: No conflict of interest was declared by the authors, Financial Disclosure: The authors declared that this study has received no financial support.

\section{References}

1. Friedlander ML, Covens A, Glasspool RM, Hilpert F, Kristensen G, Kwon S, et al. Gynecologic Cancer InterGroup (GCIG) consensus review for mullerian adenosarcoma of the female genital tract. Int J Gynecol Cancer 2014;24(9 Suppl 3):78-82. 
2. Clement PB, Oliva E, Young RH. Mullerian adenosarcoma of the uterine corpus associated with tamoxifen therapy: a report of six cases and a review of tamoxifen-associated endometrial lesions. Int J Gynecol Pathol 1996;15:222-9.

3. Bocklage T, Lee KR, Belinson JL. Uterine mullerian adenosarcoma following adenomyoma in a woman on tamoxifen therapy. Gynecol Oncol 1992;44:104-9.

4. Jessop FA, Roberts PF. Müllerian adenosarcoma of the uterus in association with tamoxifen therapy. Histopathology 2000;36:91-2.

5. Jagavkar RS, Shakespeare TP, Stevens MJ. Endometrial adenosarcoma with adjuvant tamoxifen therapy for primary breast carcinoma. Australas Radiol 1998;42:157-8

6. Arici DS, Aker H, Yildiz E, Tasyurt A. Mullerian adenosarcoma of the uterus associated with tamoxifen therapy. Arch Gynecol Obstet. 2000;264:105-7.

7. Chourmouzi D, Boulogianni G, Zarampoukas T, Drevelengas A. Sonography and MRI of tamoxifen-associated müllerian adenosarcoma of the uterus. AJR Am J Roentgenol 2003;181:1673-5.
8. Soh E, Eleti A, Jimenez-Linan M, Arends MJ, Latimer J, Sala E. Magnetic resonance imaging findings of tamoxifen-associated uterine Müllerian adenosarcoma: a case report. Acta Radiol 2008;49:848-51.

9. Kennedy MM, Baigrie CF, Manek S. Tamoxifen and the endometrium: review of 102 cases and comparison with HRTrelated and non-HRT-related endometrial pathology. Int J Gynecol Pathol 1999;18:130-7.

10. Seidman JD, Wasserman CS, Aye LM, MacKoul PJ, O'Leary TJ. Cluster of uterine mullerian adenosarcoma in the Washington, DC metropolitan area with high incidence of sarcomatous overgrowth. Am J Surg Pathol 1999;23:809-14.

11. Farhat F, Fakhruddine N. A case of synchronous relapse of breast cancer and uterine müllerian adenosarcoma post tamoxifen in a premenopausal woman. Eur J Gynaecol Oncol 2008;29:95-7.

12. Carroll A, Ramirez PT, Westin SN, Soliman PT, Munsell MF, Nick AM, et al. Uterine adenosarcoma: an analysis on management, outcomes, and risk factors for recurrence. Gynecol Oncol 2014;135:455-61. 